\title{
DIE BYBELS REFORMATORIESE TEOLOGIE EN DIE BEGRIP VOLK EN NASIONALISME.
}

\author{
deur
}

DS. J. H. KOEKEMOER

\section{INLEIDING :}

Dit is die Reformasie wat die Bybel weer sy regmatige plek in die kerk laat kry het. Want dit was die Reformatore wat andermaal die Bybel erken het as die enigste bron en norm van ons geloof, leer en lewe.

Die Roomse kerk daarenteen het aanspraak daarop gemaak en hulle doen dit vandag nog, ,dat in die woord van die kerklike leeramp die Gees ipso facto spreek. Hieruit ontstaan dan die tradisie prinsiep en die leer van die onfeilbare leergesag van die Pous". '). Die Skrif is dan alleen maar 'n belangrike bestanddeel van die kerklike oorlewing. Vir Rome gaan die kerk ontologies aan die Woord vooraf. „Die Skrif is niks anders as die getuienis van Christus, van Sy menswording en verlossing en van Sy voortdurende vleeswording in die kerk. Die kerk is die liggaam van Christus wat onlosmaaklik verbonde is aan die Hoof en die Skrif is hiervan die nadere getuienis. Daarom is die kerk nie aan die Skrif gebonde nie maar uitsluitend en alleen aan Christus". ${ }^{2}$ ) Die Skrif kom uit die kerk voort en die egtheid van die Skrif word deur die kerk bewys. In die kerk woon die Heilige Gees wat nooit van haar geskei kan word nie en wat na belofte haar in alle waarheid sal lei.

Dit is teen hierdie Roomse leer wat die sesde artikel van die Nederlandse geloofsbelydenis gemik is. Dit is hierteenoor wat die Reformasie gekom het met sy leer van die Sola Scriptura. Vir die Reformasie word die wyse waarop ons God volgens Sy eis moet dien volkomelik in die Heilige Skrif beskrywe. „Daarom is dit aan geen mens ,al was dit ook die apostels, geoorloof om anders te leer as wat ons alreeds geleer word deur die Heilige Skrif nie." ${ }^{3}$ ). Ons kan dit ook stel soos Calvyn dit gedoen het: „Die foutlose maat beide van dink en spreek, moet van die Skrif afkomstig wees." ") Daarom sal ons ook

\section{AANHALINGS.}

1) O. Weber, Grundlagen der Dogmatik, erster band, Neukirchen-Moers, bls. 252.

2) O. Weber, a.w., bls. 252.

3) Nederlandse Geloofsbelydenis artikel VII.

t) Calvyn Institusie, 1, 13, 3 . 
hier op Bybels verantwoorde wyse hierdie begrippe moet probeer bepaal.

\section{BEGRIPSBEPALINGE :}

(a) Bybels Reformatoriese Teologie:

$\mathrm{Na}$ wat ons hierbo gestel het is dit duidelik dat Reformatoriese Teologie altyd ' $n$ Bybels verantwoorde Teologie moet wees. Dit sal 'n teologie wees wat aan die Heilige Skrif gebinde is en niks anders kan of wil weergee as die Bybelse getuienis nie. Reformatoriese teologie sal altyd Skrifgebonde wees, dit sal altyd Bybelse teologie wees.

Die ou dilemma, „Teologie is kennis van God wat 'n mens dan met die rede moet probeer verstaan ... . of teologie is kennis van die religieuse mens, van die religie, waarby ons God nie nodig het nie" s) is vir ons onaanvaarbaar. Ook die beskouing van die negentiende eeu waar mense, daartoe voorberei deur sekere spiritualistiese, humanistiese en rasionalistiese gedagtes, en onder inspirasie van Schleiermacher, die uitgangspunt van die teologie in die mens self gesoek het, gaan nie op nie. „Want so word die teologie dan gesien as die wetenskap van die godsdienstige verskynsele". ${ }^{6}$ ) Teologie is vir ons die wetenskap wat hom besig hou met die openbaring van God in Jesus Christus soos dit in die openbaringsgetuienis van die Skrif gegee word. Dit is „die wetenskap van die openbaring, nie 'n geopenbaarde wetenskap nie". ') „Die taak van die teologie is om die Heilige Skrif as Woord van God so te bestudeer dat ons daardeur al die gegewens van die Skrif leer sien in hulle historiese betekenis en in hulle betekenis vir ons Christelike geloof en lewe in die kerk en wêreld". ${ }^{8}$ )

'n Ander belangrike saak om te onthou is dat teologie eintlik nie buite die kerk en los van die kerk beoefen kan word nie. Want dit gaan in die teologie om die geloof. Om die teologie en die kerk te wil skei is om aan beide die doodsteek te wil gee. Die kerk moet altyd besig wees om teologie te beoefen, die gelowige moet in die kerk en saam met die kerk die wetenskap van die teologie beoefen. „Met die selfondersoekende vraag na sy syn en wese en na die inhoud van sy

5) G. v.d. Leeuw, Inleiding tot de Theologie, Amsterdam, MCMXLVIII, bls. 105.

6) Ensiklopedie van het Christendom, Protestants deel, Amsterdam, ELSEVIER, Brussel, MCMLV, bls. 691 .

i) G. v.d. Leeuw, a.w., bls. 113.

8) B. W. Ganzevoort, Inleiding in de Theologie, J. H. Kok N.V. Kampen 1955 , bls. 47. 
opdrag en taak, sowel as na die beste metode om dit in hierdie besondere wêreldsituasie te vervul, is die kerk besig om teologie te beoefen. En as die teologie kritiese selfondersoek is van die kerk met die oog op sy regte verkondiging, sowel as korreksie van sy teologiese insigte en uitsprake deur gehoorsame luister na die openbaringsgetuienis van die Skrif, is dit seker baie nodig, gesien die feit dat die kerk hom vandag weer bevind in 'n situasie wat uiterlike ooreenkoms vertoon met die tyd toe hy sy teologiese werksaamheid begin het, om die vergissings van die begintyd deeglik onder oë te sien, met die oog op die voorkoming van hulle herhaling in hierdie nuwe situasie". ")

Reformatoriese teologie is dus in sy wese altyd die teologie van die Woord. Die teologie wat die kerk beoefen in gehoorsaamheid aan die Woord, onder die Woord en in die lig van die Woord. Die teologie wat die christengelowige in die kerk en saam met die kerk in gehoorsaamheid aan die Woord beoefen.

\section{(b) Die begrip volk :}

In die Ou Testament word veral twee woorde vir die begrip volk gebruik. Hulle is 'am en gojim (meerv.). Ons merk daarby twee dinge op:

(i) Sowel Israel as die ander volke word met beide hierdie woorde aangedui.

(ii) Veral in die jongere maar ook in die ouere gedeeltes van die $\mathrm{Ou}$ Testament word 'am eensydig gebruik vir die volk van God. Gójim word dan 'n vakterm vir die ander volke, sodat dit vertaal kan word met "heidene". Dieselfde assosiasies wat ons by die hoor van die woord "heidene" kry, kry die Israeliet by die woord gójim". Met die woord is dan 'n godsdienstige oordeel oor die volke uitgespreek". ${ }^{11}$ )

Israel is die volk van Jahwe, die 'am Jahwe, dit is die volk van die verbond. „Die volk en Jahwe staan in 'n besondere verhouding tot mekaar, hierdie verhouding vind sy gestalte in die "berith" (verbond), wat op Sinai gesluit is en reeds in die verbond met Abraham volkome aanwesig was". ${ }^{11}$ ) Op hierdie wyse is Israel onderskei van die ander volke. So word hulle dan ook die Heilige volk genoem, d.w.s. hulle behoort volkome aan

9) F. J. van Zyl, Die Trojaanse perd in die Teologie, Herv. Teologiese Studies, Junie 1962.

10) F. J. Pop, Bybelse woorde en hun geheim, deel 1, 1957, bls. 210.

11) F. J. Pop, a.w., bls. 210. 
Jahwe en is verplig om Hom te dien volgens Sy voorskrifte. Daarom is hulle dan ook nie ' $n$ heilige volk in etiese sin nie, maar in godsdienstige sin. Hulle is dit van die moment af waarop hulle deur Jahwe van die ander volke afgesonder is. Daarom moet hulle dan ook leef soos die volk van Jahwe en nie soos die heidene nie.

Verder is dit duidelik dat Israel nie op grond van verdienste die volk van Jahwe word nie, maar op grond van die vrye daad van verkiesing van Jahwe. Israel word deur Jahwe geroep om in hierdie wêreld midde in die ander volkere, Sy volk te wees, d.i. hulle is geroepe om Sy Naam te verkondig, te eer en te prys. Hulle word deur Jahwe geroep om sy deugde te verkondig. Hulle roeping is 'n roeping tot diens. „Om vir al die geslagte van die aarde tot 'n seën te wees". (Gen. 12:3.) „'n Lig van die nasies om my heil te wees tot aan die einde van die aarde". (Jes. 49:6.) Nie ter wille van die geroepene vind die roeping plaas nie, want dan sou daar iets voortrefliks in die geroepane moet wees. Maar ter wille van Gods heilsplan met die wêreld vind Sy roeping plaas. So 'n roeping is genade, heerlike genade.

In die Nuwe Testament word die woord laos gebruik vir die gemeente van Jesus Christus, die nuwe Israel. Hier is laos 'n suiwer godsdienstige begrip. Belangrik is egter om te onthou dat dit nie gepaard gaan met die opheffing van volks- en kultuurverskille nie, want die Bybel ken ook die begrip volk in 'n ander sin. Dan dui dit die volkere van die wêreld aan, bepaal deur ras, bloed en bodem. En die reggeaarde Christen erken die geskiedenis en verskille tussen rasse, volke en groepe as Gods werk en daarom natuurlik en ook menslik. Hy leer dit in die Skrif en daarom wil hy dit eerbiedig sien.

In hierdie sin is 'n volk 'n vorm van gemeenskapslewe wat wyer en groter is as die lewe van die gesin, party of groep . . . Meer as net die totaal van 'n aantal individue of gesinne of groepe, is die volk van die vervlegting van 'n menigte samebindende tendense wat mense byeen bring en byeen hou. Dit is 'n gemeenskapsvorm wat histories en natuurlik so gegroei het. 'n Volk word deur gemeenskaplike ideale en deur 'n spesifieke tradisiegebonde selfbewussyn saamgebind. En dit is goed so, want die Skrif leer dat die gesamentlike erfgoed van die vadere as 'n kosbare kleinnood bewaar moet word. In die Bybel gaan dit altyd om 'n besondere volk en sy land en in verband hiermee oor volkere en hulle lande. God roep 'n bepaalde volk ter wille van Sy heilsplan met die wêreld, bv. Israel. In die Nuwe 
En nou is die taak van die kerk ten opsigte van die volk dat die volk in die kerk die suiwere Woord van God moet vind. Die kerk moet aan die volk die evangelie predik volgens die Skrif. „Dit is in die eerste plek die volk wat getref word deur die aanslag van die verkondigde Woord. Die kerk wat teenoor en in die midde van die volk te staan gekom het as apostel, kan niks anders wees as volkskerk nie, volkskerk wat solidêr is met die volk (vergelyk Ex. 32:32; Hosea; Paulus, Rom. 9:3). Verder volkskerk wat in die midde van die volk staan, midde in die politiek, kultuur, ekonomie en gemeenskapslewe van die volk - maar daar staan as apostel, met die proklamasie van die Godsheerskappy, as dienaar en getuie van die Godsgemeenskap". ${ }^{12}$ ) Die taak van die kerk as volk van God is altyd om aan die volkere van die wêreld, met inagneming van hulle volksverband, taal en kultuurverskille, die Woord van God te verkondig. Die godsdienstige lewe moet deur die prediking van die Evangelie by elke groep 'n eie gestalte aanneem". ${ }^{13}$ ) Op hierdie wyse word mense nie losgemaak uit hulle volksverband nie en so ontwortel nie, maar word die evangelie op die beste manier gedien.

„Vir die liberalistiese lewensbeskouing is 'n volk egter niks meer as 'n konglomeraat van aparte, losstaande, vrye individue nie. 'n Gemeenskaplike, insluitende sentiment waarby die vreemde of nie-volkse tot op 'n sekere hoogte uitgesluit is, staan in kwade reuk". Die binding van die lewensverband .... of dit taal, kultuur, politiek of godsdiens is, moet so los moontlik en vir die gerief van die enkeling wees ... nie ook vir sy dissiplinering nie. Die volkseie, godsdienseie, kultuureie, taaleie, tradisie-eie, is ewe maklik verhandelbaar vir die „algemeenmenslike". Die liberalis is 'n swak vereerder van sy eie geskiedenis. Hy wil maar vergewe en vergeet. Die verlede is bloot 'n blok aan die been. Daar moenie grense tussen mense wees nie . . . nie 'n kleurslagboom nie, maar hoogstens die toets van beskawingspeil mag aangelè word; nie beskerming van jou eie teenoor die vreemde nie, nie nasietrots en patriotisme nie".

Dit is duidelik dat hierdie nie 'n Bybelse gedagte is nie. Dit word ook nêrens by die Reformatore teruggevind nie. Die

12) J. P. Oberholzer, Die apostolaat van die kerk in hierdie tyd t.o.v. die binne en buiteland, Herv. Teologiese studies, Oktober 1960.

13) H. P. Wolmarans, Artikel 111 van die kerkwet van die Ned. Herv Kerk van Afrika, Herv. Teologiese studies, Oktober $196 \mathrm{C}$. 
Reformatore wou nooit die sosiale orde ophef nie. Daar is gepleit vir die behoud daarvan. Ons herinner aan die uitspraak van Calvyn: „Non tolit ordinem sosialem”. Dit is duidelik dat die bedoeling van die liberaliste nie is om die evangelie te dien nie maar te vermoor. God is die Skepper van rasse, volke en groepe. Dit leer ons reeds uit Gen. 11. Terwyl ons verder ook weet dat bestaande verhoudinge deur die evangelie nie noodwendig opgehef word nie, maar gekersten word. Waar die verhoudinge van gesag, verwantskap ensovoorts binne dic heidense samelewing deur die sendingarbeid vernietig word, vind ontworteling plaas. Waar die kerk tussen die heidensvolk en die evangelie staan, word ontwortel, nie geplant nie. En as dic Christus-evangelie kerkvorming tot gevolg het, is daardie kerk in die eerste plek volkskerk.

\section{(c) Die begrip nasionalisme :}

Vir die liberalis is nasionalisme as 'n stuwende krag binne die volk 'n onding. Want die liberalis is ingestel op wêreldburgerskap . . . 'n uitvee van alle volksverskille en 'n vergeet van alle nasionale ideale. „Die volkseie, godsdienseie, kultuureie, taaleie, tradisie-eie is verhandelbaar vir die algemeen menslike". Daar mag geen nasietrots en patriotisme bestaan nie.

By die Wêreldraad van Kerke vind ons dat daar gepraat word van twee soorte nasionalisme. Die een soort is gehou op die verafgoding van die nasie. Dit word, so kom dit voor, veral gemik teen die westerse blanke nasionalisme en dan meer bəpaald die Afrikaner- nasionalisme. Immers „Vertraagde Aksie” het ook gestel dat dit die Afrikaner-nasionalisme is". ${ }^{1+}$ )

Die ander soort nasionalisme is dié van Afrika en Asië. Dit is "die ontwaking van volkere tot 'n bewuswording van hulls menswaardigheid". ${ }^{15}$ ) Hierdie soort nasionalisme word deur die Wêreldraad van Kerke aangeprys. Hier stel hulle dan ook dat elke vorm van segregasie afgekeur word as ontkenning van menswaardigheid. „Omdat dit stry teen alles wat die christelike gemeenskap glo oor die liefde van God vir al Sy kinders". "i) Hier moet die taak van die kerk volgens hulle wees „om te help om nasionalistiese bewegings na regverdige en waardige doeleindes te lei". ${ }^{17}$ )

14) B. J. Engelbrecht, Die kommunistiese aanslag on die kerk - Christendom teen kommunisme, Uitgegee deur die Volkskongres oor Kommunisme, 1964, bls. 43.

15) B. J. Engelbrecht, a.w. bls. 43

16) B. J. Engelbrecht, a.w. bls. 43.

ii) B. J. Engelbrecht, a.w. bls. 44. 
Vir ons gevoel is nasionalisme wat Bybels gefundeer is en Reformatories regverdigbaar is, 'n nasionalisme wat inhou die liefde vir die eie volk met erkenning van ander volke om hulle eie lief te hê. Dan staan dit in diens van God en is daar aan God verantwoordelikheid verskuldig. En wanneer die „eerste en hoogste verlange van elke lid van die volk is dat die hele volk volk van God sal wees, dan word 'n ware Christelike, geheiligde nasionalisme gebore". ${ }^{18}$ ) Bybels-Reformatories is dit korrek. Hier word nie net 'n ideaal vir eie volk gestel nie, maar gestel dat elke volk met verantwoording aan God, in gehoorsaamheid aan Sy Woord, met inagneming van die ander ideale mag hê. So 'n nasionalisme is Bybels gefundeer en Reformatories regverdigbaar.

Want die nasionalistiese gedagte is nie vreemd aan die Bybel nie. Inteendeel, in die Ou Testament staan die nasionale idee sterk voorop. Exodus beskryf die geboorte van die Israelitiese nasie en hoe God hierdie plan deurvoer nieteenstaande allê vyandige pogings van Egipte om dit te verhinder. „Moses brand van liefde vir sy verdrukte volk in wording". ${ }^{19}$ )

„Die Israelitiese nasie word dan uit die in Egipte verslaafde nakomelinge van Abram, Isak en Jakob, en 'n nie versweë inslag van gemengde bloed (Ex. 12 vers 38, Num. 11 vers 14 ) gevorm en kry sy nasionale beslag en program by die Godsberg HorebSinai. Die weg van God op aarde skyn voortaan in 'n nasionale baan te gaan loop". ${ }^{20}$ ) Verder is dit ook duidelik dat die groot Skrifprofete nasionaal gesind was. Ook in die Nuwe Testament is daar plek om die eie volk en kultuur lief te hê. En ons wil dit as ons weloorwoë mening stel dat waar die ideaal bestaan om die eie volk in stand te hou met 'n eie selfstandige entiteit en hierdie ideaal nie net geld vir die eie nie, maar vir elke ander volk, daar kry ons 'n Christelik-nasionale gedagte. 'n Nasionalisme wat Christelik gefundeer is en ook Bybels-Reformatories regverdigbaar is. Want hier is geen sprake van die verafogding van die nasie nie. Hier is ewemin sprake van nasionalisme ter wille van nasionalisme. Hier gaan dit oor 'n gehoorsame luister na die spreke van die Skrif en 'n dien van God volgens die eise van Sy Woord, ook binne die volksverband en in die nasionale ideale. So 'n nasionalisme is onontbeerlik vir'n selfrespekterende volk en is ook sedelik goed.

18) F. J. van Zvl. Ons kerk en ons volk. Die Almanak va ndie Ned. Herv. Kerk van Afrika. 1942.

19) B. Gemser, Nasionalisme en Universalisme in die prediking van die Ou Testament, Die Almanak van die Ned. Herv. Kerk van Afrika. 1940.

2ii) B. Gemser, a.w., 1940. 